\title{
Techno-Park Assistance in Mining Regions' Integration into the Innovative Economy
}

\author{
Oleg Kalenov ${ }^{1, *}$, and Sergey Kukushkin ${ }^{1}$ \\ ${ }^{1}$ Plekhanov Russian University of Economics, Academic Department of Industrial Economics, 117997, Moscow, \\ 36 Stremyanny lane, Russia
}

\begin{abstract}
A characteristic feature of the innovative economy is the increasing role of human capital, knowledge and high technologies. According to the indicators of innovative development, Russia lags behind the Western countries. At the same time, the development of Russian regions is extremely uneven. First of all, this applies to the mining regions. Technological parks should bridge the gaps and help the mining regions to integrate into the new economy. The authors consider the essence of techno-parks, the history of their establishment in Russia, and also analyze the dynamics of the main indicators of their functioning. When considering techno-park structures of the Tomsk and Kemerovo regions, the most important problems inherent these regions are highlighted. The authors analyze in detail the results of the innovation territorial center "ITC Tomsk" and the Kuzbass Techno-park, determine the main activities for the integration of mining regions in the innovation economy and characterize the positive effect of the techno-park structures functioning.
\end{abstract}

\section{Introduction}

In the conditions of establishing the information society and innovative economy, longterm economic growth is determined mainly by intensive factors provided by the active development of the most progressive achievements of science and technology. According to the majority of researchers, knowledge becomes the main factor of long-term growth of well-being both of the country as a whole and of its separate regions. The ability to master new knowledge, and consequently, technological changes, is a determining factor in the growth of the scale of regional and national economies. One of the material products of this process is innovation. In modern conditions, the main instrument for activating innovation is techno-park structures. These organizational forms create favorable conditions for the development of innovations and contribute to the acceleration of their distribution at the regional level.

To achieve a high level of innovative development of Russia, it is necessary to begin modernization from regions as a part of the country's territorial economic system. However, not all regions are characterized by an equally high level of innovation and technological development. At the basis of mining regions' economy are, as a rule, low-technology and non-science-intensive industries, which are predominantly in the primary sector of

\footnotetext{
* Corresponding author: oekalenov@yandex.ru
} 
economy. That is why, for their successful integration into new economic realities, special approaches and tools are needed that take into account the specifics of such regions.

\section{Materials and Methods}

Issues of economic development in general, and innovative development, the formation and distribution of innovations in particular, are widely covered both by Russian and foreign authors, among which are publications by the following authors: G. Mensch [1], J. Schumpeter [2], B. Lundvalla [3], N. Kondratiev [4], S. Glazyev [5], S. Zhironkin [6], M. Prokudina [7], etc. The problems of innovative and technological development of the regions were considered in the works of E. Shavina [8], E. Dotsenko [9] and N. Ezdina [10].

To assess the innovative and technological potential of the mining regions and determine the prospects for their integration into the new economy, it is advisable to use the example of two mining regions - the Tomsk and Kemerovo regions with their techno-park structures - Innovation Territorial Center "ITC Tomsk" and the Kuzbass Technopark.

The analysis of the above-mentioned techno-park structures will allow us understanding how the regions are ready to move to an innovative development path and to assess the possibility of their integration into the new economy. For the study, key industrial regions of Russia were selected. Thus, Kemerovo region produces more than $50 \%$ of coal in the country, a significant part of iron and steel smelting, as well as the production of finished rolled ferrous metals. In the mineral wealth of the Tomsk region various minerals are concentrated that make up its resource potential. The most important energy raw materials are hydrocarbons, which ensure the highest level of replenishment of the budget and inflow of investments. The Tomsk Region is one of the leading regions of Russia in gas production. There are up to 7.5 billion tons of conventional hydrocarbons in its mineral wealth. Thus, the mineral and raw materials specialization of the Tomsk region, connected with the functioning of the oil and gas complex, as well as the creation of a fundamentally new mining complex from the ground, are the main "locomotive" of the regional economy. Proceeding from this, the problem of innovation and technological development here is particularly relevant.

\section{Results and discussion}

The main techno-park structures, representing a complex form of organization of interaction of fundamental science with production, are techno-parks and technopolises.

A techno-park is understood as a complex of technological, communal and transport infrastructure managed by the management company, which provides a full range of services for the placement of its residents [11]. Large technological platforms that can meet the needs of not only small businesses, but large-scale projects of medium and large business, are referred to technopolises.

Techno-parks and technopolis have received a new impetus for development in Russia at the end of the first decade of two thousand. It was this format of providing conditions for the creation and growth of high-tech production that was recognized as the most effective and received state support, and within the framework of the Strategy for the Development of Small and Medium-Sized Enterprises until 2030.

In modern economic realities, the techno-park, first of all, is the point of growth of innovative production. The ultimate goal is the growth of the region's well-being through the creation of sites for the development and launch of new high-tech products [12]. 
The specialized site creates an active business environment due to a number of factors. They are the following: first, the unification of academic science, research and industrial complexes, business (including start-ups), investment companies and the state; second, the provision of the necessary infrastructure and services. Thus, start-up companies gain access to technical, scientific, financial resources and qualified personnel, and the state is the impetus for development in the sphere of new technologies.

Modern technological platforms are "umbrella" structures - they represent an organization, due to the support of which other, often smaller structures are being developed. Techno-parks under their "umbrella" ensure the development of start-up business organizations, providing them with access to infrastructure and support services. The author of the idea submits the project for approval and, having got the approval, becomes a resident of the park. Firms-residents can use the infrastructure of the site on favorable terms, as well as additional services that include consulting, legal services, accounting, patent and license support, etc. The technology park's additional services may include financing or assistance in attracting investments. Techno-parks have the status of special economic zones; therefore their residents enjoy tax benefits and other preferences.

At the legislation level two main types of technology parks are provided:

- industrial, ensuring the creation and launch of industrial products on the market. At the same time, at least half of the park's areas should be provided for residents - manufacturing enterprises;

- in the sphere of high technologies, ensuring the creation and launch of high-tech products on the market, including by integration with scientific organizations.

The site can combine both types or have a narrower specialization.

Techno-parks began to be established in the Russian Federation in the early 1990s. The first techno-park was set up in Tomsk in 1990 and was called "Tomsk Science and Technology Park". In the early 1990s, there was a rapid growth in the number of organized and registered techno-parks in Russia $(1990$ - 2, 1991 - 8, 1992 - 24, 1993 - 43). In the mid1990 s, their number continued to increase, and there were techno-parks organized on the basis of state scientific centers, in academic towns, science cities, in previously closed settlements. However, the rapid growth of technology parks and subsequent quantitative regression occurred due to the lack of a coherent strategy of the state in the creation and development of techno-parks, the weak material and financial base of techno-parks, and dependence on higher education institutions. As a result, by 2006 only 4 techno-parks created earlier continued to function (Fig. 1).

The second phase of the large-scale creation and development of industrial parks in Russia (since 2006 - present) has been associated with the implementation of purposeful state policy on formation of the national innovation system. At the federal level, the implementation of targeted programs for the development of technology parks on the territory of the Russian Federation began. According to the Association of clusters and technology parks, in Russia at the end of 2017 there were 192 organizations (at the end of 2016 - 203 organizations), which can be on certain grounds referred to specialized sites. The criteria of the technological park correspond to 125 organizations in 2017, in 2016 107 , and this is $50 \%$ more than in 2015 . Such growth rate of parks is due to, above all, the government support, and the relatively favorable conditions for entering the market of domestic products and technologies that support ongoing policy of import substitution. 


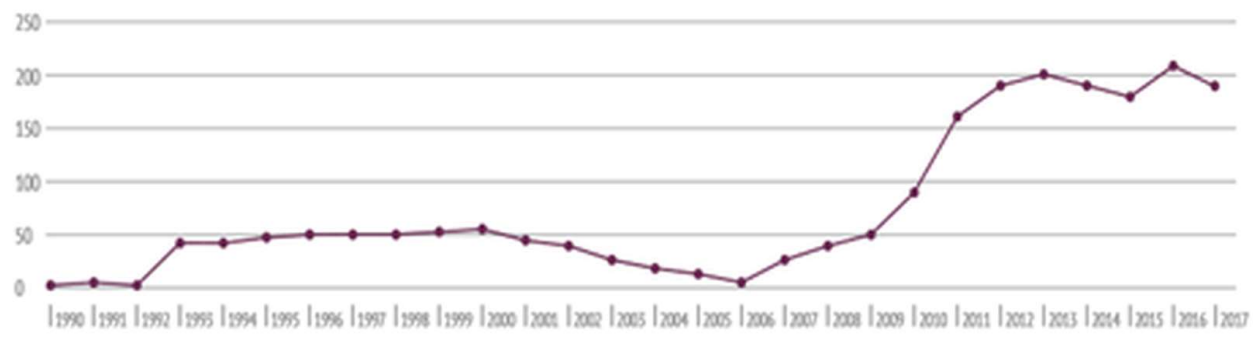

Fig. 1. The dynamics of creation Russian techno-parks in 1990-2017.

Nevertheless, the positive dynamics of the number of Russian techno-parks does not indicate the effectiveness of their functioning. International statistics show the opposite (Table 1). The payback period of techno-parks in Germany, Finland and China is about 1012 years, whereas in Russia the majority of technopark structures did not reach the breakeven point. The number of residents of Russian techno-parks, as a rule, does not exceed 200, whereas in Germany and China they are more than 1000, while the areas of Russian technopark structures considerably exceed foreign counterparts. However, the level of areas using is still not the greatest. In recent years, it fluctuates around $65-70 \%$, which indicates a significant potential for increasing the scale of activity of techno-park structures.

Table 1. The features of creation and development of techno-parks in different countries.

\begin{tabular}{|l|c|c|c|c|c|}
\hline $\begin{array}{l}\text { Number of } \\
\text { techno-parks }\end{array}$ & 125 & 360 & 77 & 24 & 83 \\
\hline $\begin{array}{l}\text { Establishing } \\
\text { period }\end{array}$ & $\begin{array}{c}\text { The first stage } \\
-1990 \mathrm{~s} \text {; the } \\
\text { second }-2006\end{array}$ & $\begin{array}{c}\text { Mid- } \\
1980 \mathrm{~s}\end{array}$ & $\begin{array}{c}\text { The mid- } \\
1970 \mathrm{~s}- \\
\text { early } 1980 \mathrm{~s}\end{array}$ & $\begin{array}{c}\text { Mid- } \\
1980 \mathrm{~s}\end{array}$ & $\begin{array}{c}\text { End of the } \\
1980 \mathrm{~s}- \\
\text { early } 1990 \mathrm{~s}\end{array}$ \\
\hline $\begin{array}{l}\text { Payback } \\
\text { period }\end{array}$ & $\begin{array}{c}\text { Most did not } \\
\text { reach the } \\
\text { breakeven } \\
\text { point }\end{array}$ & $10-12$ & $10-15$ & $\begin{array}{c}10-12 \\
\text { years }\end{array}$ & $\begin{array}{c}10-12 \\
\text { years }\end{array}$ \\
\hline $\begin{array}{l}\text { Number of } \\
\text { resident } \\
\text { companies }\end{array}$ & $\begin{array}{c}\text { from } 4 \text { to } 212 \\
\text { units }\end{array}$ & $\begin{array}{c}\text { from } 54 \text { to } \\
1350 \text { units }\end{array}$ & $\begin{array}{c}\text { from } 14 \text { to } \\
510 \text { units }\end{array}$ & $\begin{array}{c}\text { from } 50 \text { to } \\
350 \text { units }\end{array}$ & $\begin{array}{c}\text { from } 40 \text { to } \\
3600 \text { units }\end{array}$ \\
\hline $\begin{array}{l}\text { Area of } \\
\text { facilities }\end{array}$ & $\begin{array}{c}\text { from } 4.3 \text { to } \\
353.1 \text { thous. } \\
\mathrm{m}^{2}\end{array}$ & $\begin{array}{c}\text { from } 7.4 \\
\text { to } 80 \\
\text { thous. } \mathrm{m}^{2}\end{array}$ & $\begin{array}{c}\text { from } 7.1 \text { to } \\
1100 \text { thous. } \\
\mathrm{m}^{2}\end{array}$ & $\begin{array}{c}\text { about } 20 \\
\text { thous. } \mathrm{m}^{2}\end{array}$ & from 10 to \\
30 thous. $\mathrm{m}^{2}$
\end{tabular}

Let us consider the functioning of techno-park structures by the example of Tomsk and Kemerovo regions in detail. Today the Tomsk region is widely known as one of the leading oil-and-gas producing and oil-and-gas chemical regions of the country. However, unfortunately, the information that the Tomsk region has the largest reserves of solid minerals and hydro-mineral resources is known only to a small number of specialists, geologists and managers. In the bowels of the Tomsk region, more than $57 \%$ of Russia's iron resources, more than $18 \%$ of zirconium and $9 \%$ of titanium, about $6 \%$ of aluminum, significant resources of poly-metals and noble metals, rare metal and rare-earth elements are concentrated. The region's territory ranks second in Russia in peat reserves, and is also one of the richest regions of Siberia in terms of stocks of scarce construction-and-raw materials and glass-ceramic raw materials. The development of these resources is almost zero, and the investment potential is practically unlimited. 
The creation of the Innovative Territorial Center "ITC Tomsk" should solve the problems of innovative transformations. The Center is a network of urban territories integrated for solving the tasks of innovative development and stimulating economic growth, and the transport, social, information, communication and other infrastructures that connect them. The main areas of its work are: "Advanced Production", "Science and Education", "Technological Innovations and New Business", "Smart and Comfortable City", "Business Environment". The total amount of necessary investments until 2020 is 250 billion rubles; the volume of confirmed extra-budgetary funds is $65 \%$.

The project participants are 12 federal ministries, 5 large companies, development institutions, 6 universities, 12 scientific organizations, 400 small and medium-sized innovative companies and industrial enterprises. Within the framework of the Concept, 6 urban areas of Tomsk agglomeration are being developed: industrial, innovative, scientific and educational, historical, cultural, medical and sport parks. Six clusters with specialization in petro-chemistry, nuclear technologies, timber industry, pharmaceuticals, medical equipment, IT, renewable resources, and hard-to-recover reserves are the basis for the Concept implementation. Data on the Concept implementation of "ITC Tomsk" (including those with forecasted indicators of 2020) are presented in Table 2.

Table 2. Indicators of the Concept implementation of "INO Tomsk" until 2020.

\begin{tabular}{|l|c|c|c|c|}
\hline \multicolumn{1}{|c|}{ Indicator } & $\mathbf{2 0 1 4}$ & $\mathbf{2 0 1 5}$ & $\mathbf{2 0 1 6}$ & $\begin{array}{c}\mathbf{2 0 2 0} \\
\text { (forecast) }\end{array}$ \\
\hline $\begin{array}{l}\text { The number of high-production jobs } \\
\text { (thousands) }\end{array}$ & 120.6 & 124.1 & 114.8 & 160 \\
\hline $\begin{array}{l}\text { The share of domestic expenditure on } \\
\text { research and development in gross } \\
\text { regional product (\%) }\end{array}$ & 2.3 & 2.46 & 2.08 & 2.4 \\
\hline $\begin{array}{l}\text { The volume of investment in fixed } \\
\text { assets (as a percentage of the gross } \\
\text { regional product) }\end{array}$ & 22.7 & 22.8 & 20.1 & 27 \\
\hline $\begin{array}{l}\text { Production index of manufacturing } \\
\text { industry of Tomsk region (in } \\
\text { percentages to the previous year) }\end{array}$ & 102.2 & 100.6 & 101.8 & 103.1 \\
\hline $\begin{array}{l}\text { The number of publications of Tomsk } \\
\text { universities on 100 researchers in the } \\
\text { world scientific journals, indexed in } \\
\text { WEB of Science database }\end{array}$ & 21 & 60 & 75 & 24 \\
\hline $\begin{array}{l}\text { The volume of private investment of } \\
\text { residents of the SEZ T\&I "Tomsk" }\end{array}$ & 1.25 & 1.9 & 2.2 & 5 \\
\hline $\begin{array}{l}\text { The volume of goods (services) } \\
\text { produced (provided) by the residents } \\
\text { of SEZ T\&I "Tomsk" }\end{array}$ & 0.7 & 2.24 & 2.7 & 9.7 \\
\hline $\begin{array}{l}\text { The number of realized projects of } \\
\text { public spaces of city importance in } \\
\text { Tomsk }\end{array}$ & - & 2 & 13 & 15 \\
\hline
\end{tabular}

As it can be seen from the data in Table 2, by 2020, the Innovative Territorial Center should ensure the creation of 160,000 highly skilled workers, while in 2016 the results were obvious: 114.8 thousand jobs have been created. The volume of investment in fixed assets should also increase from $20.1 \%$ in 2016 to $27 \%$ by 2020 . At the same time, an increase in the share of domestic expenditure on research and development in the gross regional product is practically not provided: $2014-2.3 \%, 2016-2.08 \%, 2020-2.4 \%$. Significant growth is forecasted for the volume of goods and services produced by residents of the 
innovative center (in 2016 - 2.7, in 2020 - 9.7). The growth of private investment is also provided. The indicator should increase in more than 2 times from 2.2 to 5 .

In the Kemerovo region the situation is similar. Its raw material orientation of the economy had an impact on innovative developments. Other regions of the Siberian Federal District are considerably in advance in this direction. In 2015, the Kemerovo Region has introduced 8 innovative technologies, while the Irkutsk and Novosibirsk regions - more than 20. The main element of the innovation infrastructure of the Kemerovo region is the Kuzbass Technopark, located on the area of 23.3 hectares and having premises area of 16.5 thousand $\mathrm{m}^{2}$. The infrastructure of the technopark includes the engineering center, the production and laboratory building Ecology and Nature Management, the business incubator, the co-working center, and the center for youth innovative creativity. Its functions include: research of raw and commodity markets, search for information about technologies; provision of infrastructure for business; assistance in the promotion of projects and technologies to target markets; assistance in reducing administrative barriers, mediation in cooperation with state and supervisory bodies; assistance in attracting finance to projects at different stages of implementation; assistance in the introduction of new management technologies that increase the efficiency of project implementation.

Kuzbass techno-park promotes the transfer of enterprises of key industries to a new technological level, increasing the efficiency of nature management and minimizing the technogenic impact on the environment. For the period 2010-2016 the Kuzbass techno-park supported 60 resident companies implementing innovative projects, of which 21 residents were located on the territory of the techno-park. During this period, more than 356 requests for support were considered, 173 innovative projects passed an expert council, and 53 projects received regional tax incentives. The number of residents in 2016 was 28, including 26 small and medium-sized enterprises. At the same time, only $34 \%$ of areas are used.

The total investment volume of resident companies for 2010-2016 amounted to 11 billion rubles, the volume of capital investments -8.7 billion rubles, 1,705 new jobs were created. The aggregate volume of the received income of residents during 2010-2016 amounted to 14.5 billion rubles, the amount of tax deductions of resident companies -2.6 billion rubles. At the same time, in 2016, the residents' income amounted to 2.3 billion rubles, the volume of tax deductions -0.420 billion rubles, 1,060 jobs were created. The volume of investments from the budget of various levels accumulated 920.3 million rubles. Of these, 412.9 million rubles are the funds from the federal budget (44.9\%), 507.4 million rubles are the investments from the regional budget (50.1\%).

Thus, in most of the activity indicators of techno-parks both in the Russian Federation and in individually taken Innovative Territorial Center "ITC Tomsk" and the Kuzbass Techno-park, positive dynamics have been observed in recent years. However, in the near future there is a tendency to reduce the number of techno-park structures. The vector of development must shift in the direction of increasing the efficiency of already created sites.

\section{Conclusions}

On the basis of analysis, it can be concluded that in the mining regions of Russia, in particular in the Tomsk and Kemerovo regions, there are a number of problems that prevent the processes of innovation and technological development and their successful integration into the innovative economy.

The priority directions of innovative development in mining regions should be:

- implementation of a system of measures to reorient the innovation policy from supply to demand. In this regard, the research and development sector should be oriented towards solving the urgent problems of the industry. Therefore, mutual work of academic institutes, 
universities, and innovative business with large companies is needed to solve priority tasks, development of scientific research units of large companies, as well as intensification of work on creating sites for advanced production.

- creating conditions for attracting and retaining highly qualified specialists. The answer to demographic challenges should be improving the quality of life, providing access to the solution of advanced industry tasks in the workplace, as well as increasing the number of modern, high-productive jobs, etc.

- along with the creation of industrial, social and infrastructure facilities, it is necessary to implement organizational and managerial changes, increase efficiency and quality of management by applying new standards and management tools, increasing the investment attractiveness of the region, improving business conditions, improving the legislative base, and optimizing budget expenditures.

\section{Acknowledgement}

The reported study was funded by RFBR according to the research project №18-010-00325

\section{References}

1. G. Mensch, Stalemate in technology: innovations overcome the depression (Cambridge, Masachusetts, 1979)

2. J. Schumpeter, The theory of economic development (Progress, Moscow, 1982)

3. B. Lundvall, Nation system of innovation. Towards a theory of innovation and interactive learning (Pinter Publishers, London, 1992)

4. N. Kondratiev, Large cycles of conjuncture and theory of foresight ( Economics, Moscow, 2002)

5. S. Glazyev, The economic theory of technical development (Science, Moscow,1990)

6. S. Zhironkin, M. Gasanov, G. Barysheva, E. Gasanov, O. Zhironkina, G. Kayachev, E3S Web Conf., 21, 04002 (2017)

7. M. Prokudina, O. Zhironkina, O. Kalinina, M. Gasanov, F, Agafonov, E3S Web Conf., 21, 04003 (2017)

8. E. Shavina, O. Kalenov, E3S Web of Conf., 21, 04025 (2017)

9. E. Dotsenko, E3S Web of Conf., 21, 04013 (2017)

10. E. Dotsenko, N. Ezdina, A. Prilepskaya, K. Pivnyk, E3S Web of Conf., 21, 04014 (2017)

11. E. T. Cherkasova, Y. I. Ilinskaya, The knowledge economy: theory and practice, 1, 7284 (2017)

12. M. I. Chistyakov, The knowledge economy: theory and practice, 2, 22-28 (2017) 